\title{
PENGARUH PENERBITAN SUKUK TERHADAP REAKSI PASAR (SURVEY TERHADAP PERUSAHAAN-PERUSAHAAN YANG MENERBITKAN OBLIGASI SYARIAH YANG TERDAFTAR DIBURSA EFEK INDONESIA SELAMA TAHUN 2015)
}

\author{
Mulya Iskandar*1, Ridwan ${ }^{* 2}$ \\ ${ }^{1,2}$ Program Studi Akuntansi Fakultas Ekonomi dan Bisnis Universitas Syiah Kuala \\ e-mail: mulyaiskandar96@gmail.com ${ }^{* 1}$, ridwan.ibrahim@ unsyiah.ac.id ${ }^{* 2}$
}

\begin{abstract}
This study aims to determine how the influence of a sukuk instrument issuance on market reactions listed on the Indonesia Stock Exchange (IDX) during 2015. The research method used in this study is quantitative research. Quantitative research contains a relationship between cause and effect. The type of data used is secondary data, data collection used by the author is to know the relationship between two or more variables. The object to be examined in this study is the total value and rating of the issuance of Islamic bonds (sukuk) companies as independent variables and cumulative abnormal return shares of companies that issue Islamic bonds (sukuk) listed on the Indonesia Stock Exchange in 2015. The results of this study indicate the value of sukuk bond issuance and sukuk bond issuance ratings jointly affect stock returns. The value of issuing sukuk bonds partially affects stock returns and the rating of bond issuance has an effect on return.
\end{abstract}

\section{Keywords: Sukuk, Sharia Obligation, Market Reaction, Bursa Efek Indonesia}

\section{Pendahuluan}

Elemen penting yang menjadi pedoman bagi pengembangan ekonomi negri ialah pengertian pasar modal. Meningkatnya pasar modal secara signifikan merupakan ciri dari negri industrif maju dan negri industrif baru. Sebuah perusahaan dapat terdaftar pada abursa saham dilihat dari Indeks Harga Saham Gabungan (IHSG).

Pengembangan pasar modal (capital market) dapat dilihat melalui keadaan lapangan, secara makro ataupun mikro. Dampak lapangan mikro dilihat melalui : hasil (result) perusahaaan, pemberitahuan terbitnya saham, pemberitahuan divideen, dll. Sedangkan lapangan makro dilihat melalui: penurunan nilai mata uang, naiknya suku bunga dan kurs mata uang. Aspek-aspek tersebut mempengaruhi ketentuan pemodalan pasar modal (capital market).

Sesuai dengan keadaan market domestik Indonesia, bank maupun industri ekonomi syari'ah meningkat secara signifikan. Menurut data yang disediakan oleh Departemen Perbankan Syari'ah Indonesia untuk tahun 2009, selama tahun 2008 dan 2009, pemerintah mengeluarkan 4 sekuritas pemerintah Syari'ah (SBSN) dengan total Rs 19,8 T. Sejak tahun 2009, pemerintahan telah mengeluarkan sukuk, perdagangan ritel dan sukuk Global SNI 14. pengeluaran obligasi syari'ah global (sukuk) senilai \$ 650 juta, jumlah langganan melebihi 7 kali 7 miliar dolar AS

Permintaan berlebih yang besar untuk obligasi syari'ah global (sukuk) ini menunjukkan peluang sukuk menjadi sumber biaya untuk dibangunnya domestik, terutama pada prasarana pemerintahan. Pada saat yang sama, masalah obligasi syari'ah korporasi (sukuk) pada tahun 2009 berjumlah 2070 triliun rubel. Peningkatan sebesar $34,94 \%$ dibanding tahun 2008, mencapai RUR 1,5 T.

Peningkatan permodalan operasional koorporatif dapat meningkatkan produktifitas dan distributive menjadi meningkat. Kegiatan produkif serta penyaluran barang yang meningkat pesat mampu meningkatkan ekonomi pemerintahan. Ketersediaan barang yang terjamin juga mampu meningkatkan demand dari pelanggan.

Dengan demikian, teori pensinyalan yang digunakan dalam penelitian ini mengarah pada munculnya tanda bahwa investor dapat menangkap dalam kaitannya dengan berbagai informasi yang relevan memasuki pasar modal, yang bisa berarti positif dan negatif. Dalam hal hasil positif, pemberi 
modal dapat lebih tertarik memberi modal pada pasar modal, dan jika sinyal negatif, dapat memaksa pemberi modal untuk merubah haluan ke objek investasi lain yang profitable.

Sesuai dengan DSN MUI No.32/DSNMUI/IX/2002, sukuk adalah "surat utang yang dikeluarkan oleh badan usaha (pemerintah) dengan berdasarkan prinsip syari'ah, dan keuntungan yang didapat berupa bagi hasil/margin/fee akan dibagikan pada pemegang obligasi. Serta pemegang obligasi syari'ah (sukuk) membayar kembali dana obligasi pada saat batas waktu yang telah ditentukan".

Obligasi syari'ah (sukuk) harus mematuhi prinsip-prinsip Syari'ah, berdasarkan Al-Quran juga Hadits. Adanya sukuk dapat jadi jalan keluar untuk setiap aktivitas kelembagaan keuangan syari'ah. Fenomena tentang sukuk didasarkan pada observasi yang dibuat yang mana produk ini sebenarnya dipergunakan oleh komunitas Islam periode pertengahan. 2008: 139).

Investor akan menanggapi pengumuman masalah sukuk. Apabila pemberi modal menggunakan info ketika membuat kesimpulan investasi mereka, pengumuman dapat memberi dampak aterhadap berubahnya aharga asaham. Pada pengembalian saham anomali kumulatif dari Bursa Efek Indonesia untuk periode 2002-2009. (sukuk), pada saat yang sama dan sebagian tidak memiliki dampak signifikan terhadap total pengembalian saham abnormal.

Dengan demikian, penelitian ini adilakukan auntuk amempelajari apakah ada hubungan diterbitkannya sukuk, jumlah biaya penerbitan obligasi syari'ah serta jumlah masalah obligasi syari'ah pada pengembalian tidak normal agregat saham perusahaan.

\section{Kajian Teoritis \\ Signalling Theory}

Info yang diumumkan dapat memberi sinyal kepada pemberi modal saat membuat kesimpulan investasi (Hartono, 2009). Apabila iklan baik, maka pasar diharap merespons ketika iklan diterima pasar. Market bisa dipicu dengan perubahan tingkat perdagangan saham. Semasa pengumuman dan seluruh orang yang melakukan kegiatan saham di pasar mendapatkan pengetahuan mengenai pasar, orang yang bermain di pasar saham awalnya menganalisa pengetahuan tersebut sebagai hal yang baik atau sebaliknya. Sinyal positif kepada investor ialah perubahan tingkat perdagangan saham.

Hagen dan Hammerstein dalam Bird dan Smith (2005) menyimpulkan:

"The essence of signaling theory, as Bliege Bird and Smith explain, is what is variously termed private, incomplete, or asymmetrical information--some participants in a social interaction have difficult-to observe qualities that are critical to the decision making of other participants. Bliege Bird and Smith insightfully apply signaling theory to phenomena frequently observed in nonmarket economies. This theory has also been widely applied to phenomena in market economies. We agree with Bliege Bird and Smith that signaling theory is likely to be broadly useful in the socialsciences".

Oleh karena itu, signaling theory yang digunakan dalam penelitian ini lebih mengarah kepada suatu pertanda yang dapat ditangkap oleh para investor mengenai berbagai informasi yang relevan yang masuk ke pasar modal. Pertanda tersebut dapat berarti positif maupun negatif. Apabila positif, maka investor akan makin tertarik untuk berinvestasi di dalam pasar modal tersebut, dan sebaliknya pertanda yang negatif dapat membuat investor beralih kepada investee lainnya yang lebih menguntungkan.

\section{Pengertian Obligasi Syariah (Sukuk)}

Pasal 1 Keputusan "Republik Ingushetia No. 755 / KMK011 / 1982" menyatakan yaitu obligasi ialah surat berharga yang relevan meminjam uang dari rakyat dalam bentuk dan periode tertentu. Investor siap untuk bayar interest.

Sukuk menurut Juliana (2010: 152), ialah perjanjian jangka panjang secara tertulis dan mesti dibayar dalam suatu periode. Keharusan bagi investor didapatkan dari biaya sukuk. Sukuk bertujuan untuk memberi kemudahan serta biaya pada suatu janji dagang. Saat menerbitkan sukuk, Anda wajib mengikuti perjanjian perdagangan dan sesuai dengan prinsip Syari'ah. Hukum Syari'ah Negri Efek (SBSN), sukuk ialah "surat berharga yang diterbitkan oleh perusahaan / pemerintah berdasarkan prinsip Syari'ah sebagai bukti dana investasi dalam bentuk aset SBSN dengan rupee dan mata uang asing".

DSN) dalam fatwa No. 32/DSN-MUI/IX/2002, "Obligasi syari'ah (sukuk) adalah surat berharga jangka panjang berdasarkan prinsip syari'ah yang telah 
dikeluarkan badan usaha (emiten) seperti Badan Pelaksana Pasar Modal/Perusahaan kepada pemegang obligasi syari'ah (sukuk).Kemudian, penerbit wajib untuk membayar keuntungan kepada pemegang obligasi syari'ah (sukuk)".

Para penanam modal obligasi syariah (sukuk) akan mendapatkan keuntungan yang lebih besar dari pada menggunakan produk perbankan lainnya (Huda, dkk. 2008: 83). Obligasi atau bond adalah surat utang jangka panjang yang dikeluarkan oleh peminjam dengan kewajiban membayar kepada bond holder (pemegang obligasi) sesuai dengan jumlah bunga yang telah ditetapkan pada saat perjanjian.

\section{Landasan Obligasi Syariah (Sukuk)}

1) QS. Al-Baqarah: 275

Artinya: "orang-orang yang memakan riba tidak dapat berdiri melainkan seperti berdirinya orang yang kemasukan setan karena gila. Yang demikian itu, karena mereka berkata bahwa jual beli sama dengan riba. Padahal Allah telah menghalalkan jual beli dan mengharamkan riba. Barang siapa mendapat peringatan dari Tuhannya, lalu berhenti, maka apa yang telah diperplehnya dahulu menjadi miliknya dan urusannya (terserah) kepada Allah. Barang siapa mengurangi, maka mereka itupenghuni neraka, maka kekal didalamnya".

2) QS. Al Maidah : 01

Artinya "Hai orang-orang yang beriman, penuhilah aqad-aqad itu. Dihalalkan bagimu binatang ternak, kecuali yang akan dibacakan kepadamu. (Yang demikian itu) dengan tidak menghalalkan berburu ketika kamu sedang mengerjakan haji.Sesungguhnya Allah menetapkan hukum-hukum menurut yang dikehendakiNya."

\section{Jenis-Jenis Obligasi Syariah (Sukuk)}

Sukuk ijara, yaitu perjanjian tentang pengalihan hak (manfaat) untuk penggunaan barang/jasa melalui pembayaran leasing, tanpa memperhitungkan kepemilikan barang. jenis pendapatan komisi (sewa) dari aset sewaan. Obligasi ijarah Islam (sukuk) ialah sukuk sesuai dengan perjanjian ijara mengenai fatwa DSN 09 / DSNMUI / IV / 2000 atentang biaya Ijara.

Ijara adalah perjanjian tentang pengalihan hak (manfaat) untuk menggunakan item untuk era tertentu dengan era yang ditentukan amelalui pembayaran aleasing, tanpa mengalihkan kepemilikan abarang
(Gunawan 2004: 10). Sukukaljarah adalah sukuk, yang dana yang ahanya adapat adigunakan auntuk menyewakan area bisnis. Pendapatan investor diperoleh dari sewa dengan komisi tetap untuk ijara, yang ditentukan pada awal kontrak.

Dalam sukuk mudharaba ialah untuk menanam modal dengan perjanjian kerjasama antara kedua kubu, di mana kubu yang utama bertindak menjadi investor, dan yang dua - sebagai pemasok atau manajer bisnis. Manfaat yang diperoleh dari kerja sama akan dibagi secara merata sesuai dengan perjanjian pada saat kesimpulan perjanjian.

Menurut Nazaruddin (2010: 136), sekuritas dikeluarkan atas dasar kesepakatan antar dua kubu dan kerjasama agar dapat menyatukan modal mereka

Menurut Huda dan Mustafa (2008: 146), sukuk istisna, dikeluarkan sesuai serperti janji dagang yang pernah dibuat, yakni barang yang disetujui agar dapat diberikan modal oleh investor.

Fisher and Jordan (1996):

" An Investment is a commitment of funds made in the expectation some positive rate of return".

Investasi menurut Reilly (2003) :

"The current commitment of dollars for a period of time derive future payment that will compensate the investors for (1) the time of funds are committed (2) Expected rate of inflation and (3) The Uncertainity of future payment".

Investasi dapat dibagi menjadi 2 jenis: investasi dalam aset nyata dan aset keuangan. Berinvestasi dalam aset nyata berarti berinvestasi dalam hal-hal seperti mobil, bangunan, dan tanah. Sedangkan berinvestasi dalam aset keuangan berarti berinvestasi dalam sekuritas yang diperdagangkan di pasar keuangan.

\section{Metode Penelitian \\ Desain Penelitian}

Penelitian yang dilakukan ini akan menggunakan metode penelitian kuantitatif. Penelitian kuantitatif yang banyak mengandung hubungan antara sebab dan akibat, dan untuk penelitian ini sebagian besar datanya akan menggunakan angka dan dianalisis menggunakan tekhnik statistik atau data yang berupa angka, dikumpulkan dan dikelompokkan sehingga dapat memberikan informasi yang berarti muncul suatu masalah (Sangadji dan Sopiah, 2010: 26). 
Penelitian kuantitatif ini penelitian yang memiliki tujuan tersendiri yaitu untuk mengetahui hubungan antara dua variabel atau lebih yang datanya dalam bentuk angka. Dan data tersebut akan diolah dengan menggunakan tekhnik analisis statistik.

Objek yang akan diteliti dalam penelitian ini adalah data total nilai dan rating penerbitan obligasi syariah (sukuk) perusahaan sebagai variable independen, dan cumulative abnormal return saham perusahaan yang menerbitkan obligasi syariah (sukuk) serta terdaftar di Bursa Efek Indonesia pada tahun 2015 sebagai variabel dependen.

Peneliti menggunakan data perusahaanperusahaan yang sudah go public karena informasinya mudah diperoleh dan perusahaan-perusahaan tersebut telah berkewajiban untuk melaporkan laporan keuangan tahunannya kepada stakeholders perusahaan sebagai salah satu bentuk pertanggungjawaban mereka, khususnya terhadap investor. Selain itu ,informasinya pun dapat diandalkan untuk pengambilan keputusan investasi oleh investor.

\section{Populasi, Sampel dan Teknik Pengambilan Sampel Populasi}

Menurut Sugiyono (2012: 80), populasi adalah wilayah generalisasi yang terdiri atas obyek atau subyek yang mempunyai kualitas dan karakteristik tertentu yang ditetapkan oleh peneliti untuk dipelajari dan kemudian ditarik kesimpulannya. Populasi yang digunakan dalam penelitian ini adalah perusahaanperusahaan yang menerbitkan sukuk yang terdaftar di BEI tahun 2015.

\section{Sampel dan Teknik Pengambilan Sampel}

Menurut Sugiyono (2012: 81), sampel adalah bagian dari jumlah dan karakteristik yang dimiliki oleh populasi tersebut. Sementara menurut Kuncoro (2013: 123), sampel adalah sebagian dari populasi yang terpilih dari sumber data. Teknik pengambilan sampel adalah untuk mengetahui sampel yang akan digunakan dalam penelitian. Pemilihan sampel pada penelitian ini menggunakan sampel jenuh yaitu teknik penentuan sampel bila semua anggota populasi digunakan sebagai sampel atau penelitian yang ingin membuat generalisasi dengan kesalahan yang sangat kecil. Istilah lain dari sampel jenuh adalah sensus, dimana semua anggota populasi dijadikan sampel (Sugiyono, 2012: 85).

\section{Metode Penelitian}

Penelitian ini merupakan studi peristiwa (event study) yang bertujuan untuk melihat reaksi pasar modal terhadap peristiwa penerbitan obligasi syariah (sukuk) yang diwakili oleh total nilai dan rating penerbitan obligasi syariah (sukuk), yang dilakukan masing-masing perusahaan dimana perusahaan tersebut juga terdaftar di Bursa Efek Indonesia. Karena itu, ruang lingkup penelitian dibatasi pada pemilihan metodologi yang meneliti pergerakan cumulative abnormal return saham.

Penelitian ini menggunakan metode deskriptif dengan jenis penelitian survei data sekunder. Metode deskriptif digunakan untuk tujuan membuat deskripsi atau gambaran secara sistematis, faktual, dan akurat mengenai fakta-fakta serta sifat dan hubungan antara fenomena yang diselidiki (Nazir,2006). Metode ini meneliti status sekelompok manusia, suatu objek, suatu set kondisi, suatu sistem pemikiran ataupun suatu kelas peristiwa pada masa sekarang, dengan tujuan untuk membuat deskripsi atau gambaran secara sistematis, faktual, dan akurat mengenai fakta-fakta serta sifat- sifat dan hubungan antara fenomena yang diselidiki.

Peneliti telah menetapkan dugaan dasar yang kebenarannya masih perlu diuji, yang disebut dengan hipotesis. Tujuan dari hipotesis salah satunya untuk menjelaskan masalah penelitian dan pemecahannya secara rasional (Indriantoro,2002). Dalam hal ini, peneliti melakukan penelitian berdasarkan hipotesis, diawali dengan pengumpulan data yang relevan dengan hipotesis hingga pengujian hipotesis tersebut.

\section{Operasional Variabel}

Operasionalisasi variabel ini diperlukan untuk menentukan jenis dan indikator dari variabel-variabel yang terkait dalam penelitian ini. Selain itu proses ini juga dimaksudkan untuk menentukan skala pengukuran dari masing-masing variabel sehingga pengujian hipotesis dengan alat bantu statistik dapat digunakan secara benar. Dalam penelitian ini peneliti menggunakan 3 variabel penelitian yaitu 2 variabel independen dan 1 variable dependen, yaitu "Pengaruh Penerbitan Obligasi Syariah (sukuk) terhadap Reaksi Pasar (Survey pada perusahaanperusahaan yang menerbitkan obligasi syariah dan terdaftar di BursaEfek Indonesia pada tahun 2015)". 


\section{Variabel Bebas 1 (independent variable)}

Variabel independen/bebas 1 (X1) yaitu variabel nilai penerbitan obligasi syariah (sukuk) yang diwakili oleh tingkat leverage (sukuk) ratio yang dinilai sebesar perbandingan nilai nominal penerbitan obligasi dengan total ekuitas perusahaan, (sukuk equity ratio). Data ini diperoleh dengan menggunakan rumus:

$$
\text { Sukuk Equity Ratio= }=\frac{\text { Total Sukuk }}{\text { Total Ekuitas }}
$$

\section{Variabel Bebas 2 (independent variable)}

Variabel independen/bebas 2 (X2) yaitu variabel rating penerbitan obligasi syariah (sukuk) yang dikonversikan ke dalam bentuk interval dari bentuk huruf.

\section{Variabel Terikat}

Reaksi pasar mencerminkan tindakan yang dilakukan oleh investor setelah menerima informasi dari suatu peristiwa tertentu. Hartono (2008) dan Jogiyanto (2003) mengemukakan bahwa reaksi pasar dapat diukur dengan menggunakan return sebagai nilai perubahan harga atau dengan mengunakan return tidak normal (abnormal return). Abnormal return dapat diketahui dengan cara return yang sesungguhnya (actual return) dikurangi return yang diharapkan (expected return), dapat dirumuskan:

$\mathrm{RTN}_{\mathrm{i}, \mathrm{t}}=\mathrm{R}_{\mathrm{i}, \mathrm{t}}-\mathrm{E}\left(\mathrm{R}_{\mathrm{i}, \mathrm{t}}\right)$

\subsection{Hasil Penelitian}

\section{Analisis Deskriptif}

Deskripsi data memberikan gambaran atau deskripsi mengenai karakteristik data variabel yang digunakan dalam penelitian. Tabel 4.1 menunjukkan nilai stasistik deskriptif dari masing-masing variabel.

Berdasarkan Tabel 4.1 diketahui bahwa nilai minimum dan maksimum untuk cummulative abnormal return adalah sebesar -0,02342 dan 1,12211 dengan nilai rata-rata sebesar 0,07201 serta standar deviasi sebesar 0,19092. Nilai minimum dan maksimum untuk nilai penerbitan obligasi sukuk adalah sebesar 0,01989 dan 0,24702 dengan nilai ratarata sebesar 0,11213 serta standar deviasi sebesar 0,05601. Nilai minimum dan maksimum untuk rating penerbitan obligasi sukuk adalah sebesar 1 dan 3,44170 dengan nilai rata-rata sebesar 2,28700 serta standar deviasi sebesar 0,69994.

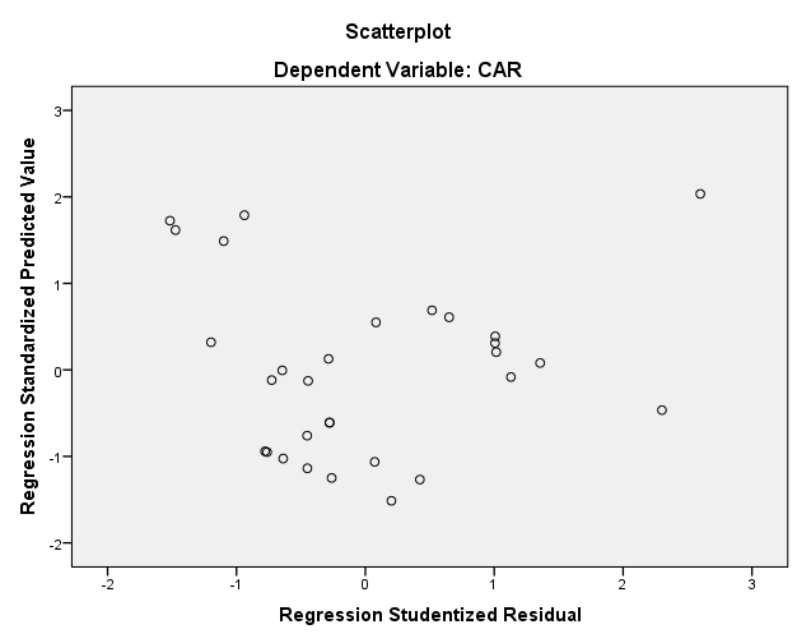

Uji Multikolineriatas

Tabel 4.3

Uji Multikolinieritas

\begin{tabular}{|c|c|c|}
\hline Variabel & VIF & Keterangan \\
\hline SER & 1,336 & Tidak terjadi gejala multikolonieritas \\
\hline RI & 1,336 & Tidak terjadi gejala multikolonieritas \\
\hline
\end{tabular}

Hasil Uji Determinasi

\begin{tabular}{|l|c|r|r|r|}
\hline Model & R & R Square & \multicolumn{1}{c|}{$\begin{array}{c}\text { Adjusted R } \\
\text { Square }\end{array}$} & $\begin{array}{l}\text { Std. Error of } \\
\text { the Estimate }\end{array}$ \\
\hline 1 & $.861^{\mathrm{a}}$ & .741 & .772 & .021293 \\
\hline
\end{tabular}

\section{Uji t (Uji Parsial)}

Untuk menguji hipotesis parsial dapat dilihat hasil uji statistik berdasarkan pengolahan data dengan menggunakan SPSS sebagaimana diasajikan pata berikut.

Adapun interpretasi dari model regresi tersebut adalah sebagai berikut.

1. Koefisien regresi dari variabel nilai penerbitan obligasi sukuk adalah sebesar 0,352. Hal ini berarti bahwa nilai penerbitan obligasi sukuk mempunyai pengaruh positif terhadap return saham dengan nilai koefisien jalur sebesar 0,352 . Nilai Sig. Sebesar $0,001<0,05$, artinya bahwa nilai penerbitan obligasi sukuk secara parsial berpengaruh terhadap return saham.

2. Koefisien regresi dari variabel rating penerbitan obligasi sukuk adalah sebesar 0,032. Hal ini berarti bahwa rating penerbitan obligasi sukuk mempunyai pengaruh positif terhadap return saham dengan nilai koefisien jalur sebesar 
0,032. Nilai Sig. Sebesar $0,000<0,05$, artinya bahwa rating penerbitan obligasi sukuk secara parsial berpengaruh terhadap return saham.

\section{Pembahasan}

\section{Pengaruh Nilai Penerbitan Obligasi Sukuk terhadap Return Saham}

Hasil dari pengujian hipotesis ini adalah variabel nilai penerbitan obligasi sukuk secara parsial berpengaruh terhadap return saham, kesimpulan ini didapat dari nilai signifikansi pada Tabel 4.6 sebesar 0,001 yang lebih kecil dari nilai alpha 0,05 . Koefisien regresi dari variabel nilai penerbitan obligasi sukuk adalah sebesar 0,352 . Hal ini berarti bahwa nilai penerbitan obligasi sukuk mempunyai pengaruh positif terhadap return saham dengan nilai koefisien jalur sebesar 0,352 .

Hasil penelitian ini konsisten dengan penelitian yang dilakukan oleh Srianingsih (2015), yang juga menunjukkan bahwa biaya penerbitan sukuk memiliki efek positif terhadap pengembalian saham. Jika biaya penerbitan sukuk ke perusahaan tinggi, maka pengembalian saham yang dihasilkan juga akan tinggi. Studi ini menunjukkan bahwa biaya penerbitan sukuk memiliki konten informasi yang cukup tentang keputusan yang dibuat oleh investor. Informasi tentang biaya penerbitan sukuk secara terpisah akan diperhitungkan oleh investor ketika membuat keputusan.

Hasil penelitian ini sejalan dengan penelitian yang dilakukan oleh Priyadi (2016) yang juga mengungkapkan bahwa rating penerbitan sukuk berpengaruh positif terhadap return saham. Keputusan investor untuk berinvestasi di pasar modal ditentukan oleh ekspektasi investor mengenai kesuksesan bisnis di masa depan. Investor akan bersedia untuk berinvestasi jika mereka mempertimbangkan prospek investasi yang menguntungkan.

Menurut Khartono (2003: 109), investor rasional akan memperhitungkan tingkat pengembalian yang diharapkan ke tingkat risiko investasi mereka. Investor akan menganalisis informasi tentang masalah sukuk, apakah akan berdampak positif atau negatif pada perusahaan. Informasi tentang rilis sukuk adalah positif jika publikasi berisi informasi yang berarti kabar baik bagi investor. Informasi yang berarti kabar baik menunjukkan bahwa sukuk dapat meningkatkan nilai perusahaan dan memberikan manfaat bagi investor, sehingga investor akan lebih tertarik berinvestasi. Demikian pula, informasi sukuk negatif jika publikasi berisi informasi yang berarti berita buruk bagi investor, sehingga investor akan beralih ke objek investasi lain yang lebih menguntungkan.

\section{Kesimpulan dan Saran \\ Kesimpulan}

Penelitian yang sedang diteiti bertujuan melihat pengaruh nilai diterbitkannya sukuk serta nilai diterbitkannya sukuk kepada return saham. Kesimpulannya adalah sebagai berikut.

1. "Nilai penerbitan sukuk dan rating penerbitan sukuk secara bersama-sama berpengaruh terhadap return saham."

2. "Nilai penerbitan sukuk secara parsial berpengaruh terhadap return saham."

3. "Nilai penerbitan sukuk secara parsial berpengaruh terhadap return saham."

\section{Saran}

Adapun saran bagi penelitian selanjutnya ialah diharapkan menambah variabel-variabel lain yang potensial dan dapat memberikan kontribusi terhadap perubahan return saham perusahaan, dan juga diharapkan memperluas populasi yang digunakan dan memperpanjang periode waktu penelitian

\section{Daftar Pustaka}

Al-Qur'an Dan Hadits.Qs Al-Baqarah;275, Qs AlMaidah ; 01

Afaf, Nafiah.2008. Analisis Pengaruh Pengumuman Penerbitan Obligasi Terhadap Return Saham Di Bursa Efek Jakarta. Tesis S2 yang Dipublikasikan

Bank Indonesia.2009. Total Surat Berharga Tahun 2008-2009. Jakarta.

Diakses pada tanggal 14 April 2018

Bird, Rebecca Bliege Smith, Eric Alden. 2005. Signalling Theory, Strategic Interaction, And Simbolic Capital. USA : The Warner

Gren Foundation for Anthoropological Research Cheng, Wei, Visaltanachoti N and Kesayan. 2005. A Stock Reaction Following Convertible Bond Issuance. Japan : International Journal Of Business. 
Dewan Syariah Nasional Majelis Ulama Indonesia. 2001. Fatwa Dewan Syariah Nasional Nomor 20/DSN-MUI/IV/2001 tentang Jenis

Kegiatan Usaha yang Bertentangan dengan Syariah Islam. 2002. Fatwa Dewan Syariah Nasional Nomor 32/ DSN-MUI/IX/2002 tentang Definisi Obligasi Syariah.

------. 2002. Fatwa Dewan Syariah Nasional Nomor 33/ DSN-MUI/IX/2002 tentang Obligasi Syariah Mudharabah.

-. 2003. Fatwa Dewan Syariah Nasional Nomor 40/ DSN-MUI/IX/2003 tentang Instrumen pasar modal syariah. Jakarta.

-------. 2004. Fatwa Dewan Syariah Nasional Nomor 41/ DSN-MUI/III/2004 tentang Obligasi Syariah Ijarah.

Elyya, Ainurrochma, Maswar. 2016. Pengaruh Nilai dan Rating Penerbitan Sukuk Serta Der Perusahaan

Fischer, Donald, Jordan Ronald J. 1996. Security Analysis and Portofolio Managament. United States Of America: Inc Englewood

Famadalam.2006. Pengertian Stock Prices menurut Famadalam. United States Of America. Inc Englewood

Ghoniyah, Mutaminah dan Widayati. 2008. Reaksi Pasar Modal Indonesia Terhadap

Pengumuman Penerbitan Obligasi Syariah. Jakarta : Simposium Nasional Akuntansi

Ghozali, Imam. 2011. Aplikasi Analisis Multivariate dengan Program IBM SPSS 19. Semarang: Universitas Diponogoro.

Gitman, Lawrence J. 2006. Principles Of Management. USA: Thomas Corporation

Gujarati, Damodar. 1995. Ekonometrika Dasar. Jakarta: Erlangga.

Gunawan Yasni. (2004). Pilih Mudharabah atau Ijarah. Modal. Edisi: 23.

Hartono, Jogiyonto. 2009. Teori Portofolio dan Analisis Investasi. Yogyakarta: BPFE Universitas Gadjah Mada

Hagen, Hammerstein.2005. The essence of Signaling Theory. United State Of America.

Akibat Suatu Peristiwa. Yogyakarta: BPFE Universitas Gadjah Mada. Edisi Pertama

Return On Assets, Return On Equity dan Earning Per Share Emiten di Bursa Efek Indonesia Tahun
2009-2013. Jurnal Ekonomi dan Bisnis. Vol. 2 No. 06.

HN, Archana dan S. Jayanna. 2015. A Study on the Impact of Bond Rating

Changes on the Stock Prices in India. Indian Journal of Applied Research 5(8).

Keputusan Kementrian Keuangan Republik Indonesia No.755/KMK/011/1982

Kamus Besar Bahasa Indonesia. Pengertian Obligasi Menurut Bahasa.

Jakarta.

Kieso, Weygandt \& Warfield. 2011. Intermediate Accounting Vol : 1

IFRS Edition. United States Of America : Wiley

Kuncoro, Mudrajat. (2013). Metode Riset untuk Bisnis dan Ekonomi

Edisi: 04. Yogyakarta

Muhammad, Nafik. (2009). Bursa Efek dan Investasi Syariah. Sinar Grafika: Jakarta.

Nazaruddin, Abdul dan Wahid. (2010). Memahami dan membedah obligasi pada perbankan syariah. Yogyaarta: A-Ruzz Media

Nazir. Mochammad. 2006. Metode penelitian. Ghalia Indonesia: Jakarta

Nurjannah dan Herlambang. (2015). The Effect of Sukuk to Total Liability and Sukuk to Total Equity against Return on Assets(Studies in Sukuk Issuers Listed in Indonesia Stock Exchange 2008-2013). Jurnal Ekonomi dan Bisnis

Procianoy, Jairo Laser. 2006. A New Signalling More Complete Explanation Investor Behavior to Corporate Announcements. Brazil.

Rama, Ali. 2009. Islamic Banking/Islamic Economics. Syarif Hidayatullah State Islamic University. Jakarta

Reilly, Frank, and Brown Keith. 2003. Investment Analysis and Portofolio Management. United States Of America: Thomas South Western Inc

Republik Indonesia. 1995. Undang-undang No.8 Tentang Pasar Modal.Jakarta . 2008. Undang-undang No 19 Tahun 2008 Tentang Surat Berharga Syariah Negara. Jakarta. Erlangga

Sawidji Widoatmodjo. 2009. Pasar Modal Indonesia: Pengantar \& Studi Kasus. Jakarta: Ghalia Indonesia 
Sekaran, Una.2013. Business Research Method.

Salemba Empat: Jakarta

Srianingsih, M khoiruddin. 2015. Pengaruh Pengumuman Peringkat Sukuk Terhadap Reaksi Pasar. Jakarta

Sugiyono. 2012. Statistika untuk Metode Penelitian. CV Alfabeta: Bandung

Suad Husnan. 2001. Dasar-Dasar Teori Portofolio dan Analasis Sekuritas Yogyakarta : UPP AMP YKPN

Suryawijaya, Marwan Asri Dan Faizal Arief Setiawan.1998. Reaksi Pasar Modal Indonesia Terhadap Peristiwa Politik Dalam Negeri (even Study pada peristiwa 27 Juli 1996). Jakarta : KELOLA

Sumardi. 2007. Analisis Pengaruh Penerbitan Obligasi Terhadap Abnormal Return Saham di Bursa Efek Jakarta Periode 2000-2006. Tesis. Jakarta : Program Studi S2 Universitas Indonesia

Yuliana, Indah. (2010). Investasi Produk Keuangan Syariah. UIN Maliki Press.

www.aaoifi.com. Diakses pada tanggal 10-11-2017

www.sahamok.com//Bapepam-Lk. Diakses pada tanggal 10-11-2017

www.idx.co.id. Diakses pada tanggal 13-10-2017 